\title{
"E POR MUCHAS OBRAS E AYUDAS QUE DE VOS HE RESÇIBIDO”. EL LINAJE GARCÍA DE LA RÚA Y TALAVERA DE LA REINA A MEDIADOS DEL SIGLO XV: EJEMPLO DE ASCENSO SOCIAL Y POLÍTICO POR SERVICIO AL SEÑOR DE LA VILLA ${ }^{1}$
}

\author{
"E POR MUCHAS OBRAS E AYUDAS QUE DE VOS HE RESÇIBIDO". \\ THE LINEAGE GARCIA DE LA RÚA AND TALAVERA DE LA REINA \\ IN THE MID-FIFTEENTH CENTURY: AN EXAMPLE OF SOCIAL AND \\ POLITICAL CLIMBING AS RESULT OF THE SERVICE TO THE LORD OF \\ THE VILLAGE
}

\author{
Alicia Lozano Castellanos \\ Universidad de Castilla-La Mancha \\ Alicia.Lozano@uclm.es
}

RESUMEN: En el presente trabajo se analiza el proceso de ascenso socio-político de la familia talaverana García de la Rúa. La trayectoria seguida por uno de sus miembros, Ruy García, se muestra como un ejemplo paradigmático de promoción social al servicio de un linaje nobiliario, en este caso, los Acuña. El culmen de su carrera, que empezó como escribano de cámara, fue la ostentación de una regiduría en el cabildo de Talavera de la Reina, gracias a la merced del arzobispo Alonso Carrillo, señor de la villa. La posición ocupada en el sistema urbano talaverano por otros miembros de la familia, integrados en la llamada "élite de participación" y monopolizando la gestión de las rentas regias del partido fiscal talaverano, facilitó la inclusión de Ruy García en grupo de poder local.

Palabras ClaVE: Corona de Castilla, siglo XV, regimiento, fiscalidad, hombres de negocios, Talavera de la Reina.

ABSTRACT: The aim of this paper is to analyze the process of social and political climbing of the family of Talavera, Garcia de la Rua. The career of one of their members, Ruy Garcia, is an example of social promotion result of the service to a

1. Este trabajo ha sido realizado en el marco del proyecto "Hombres de negocios: mercaderes y financieros en las ciudades castellano-manchegas en la Baja Edad Media" (PEII10-0070-8208), cofinanciado por la Junta de Comunidades de Castilla-La Mancha y el Fondo Social Europeo.

Abreviaturas utilizadas: ACT = Archivo de la Colegiata de Talavera de la Reina; AGS = Archivo General de Simancas; AMT = Archivo Municipal de Talavera de la Reina; ARCV = Archivo de la Real Chancillería de Valladolid; EMR = Escribanía Mayor de Rentas; LLAA = Libros de Actas; RGS = Registro General del Sello; SNAHN = Sección Nobleza del Archivo Histórico Nacional. 
noble lineage, in this case, the Acuña family. The peak of his career, which started as scribe, was his appointment as regidor in Talavera de la Reina, as a favour of Alonso Carrillo, Archbishop of Toledo and lord of the town. The social position of other members of the family in the village, as elite of participation and having the monopoly of the management of the royal taxes of the fiscal district of Talavera, made easier the inclusion of Ruy Garcia in the local power group.

Keywords: Crown of Castile, fifteenth century, regimiento, fiscality, businessmen, Talavera de la Reina.

\section{INTRODUCCIÓN}

El análisis del proceso de construcción de las carreras sociopolíticas de los principales actores dirigentes en el marco urbano, así como su integración en los grupos oligárquicos que operaban en los concejos bajomedievales castellanos, es una línea de investigación seguida, desde hace algunos años por la historiografía española ${ }^{2}$. Siguiendo un modelo paralelo, diversos autores han tratado de

2. Cabe destacar las aportaciones de investigadores como M.I. del Val, J.M. Monsalvo Antón o J.A. Jara Fuente. De M.I. del Val destacan, entre otros, textos como "La sociedad urbana del señorío de Vizcaya”, En la España Medieval, 7 (1985), pp. 317-335; "Dinámica social en las ciudades castellanas en torno a 1494" en L.A. Ribot García, A. Carrasco Martínez y L.A. da Fonseca (coords.). El tratado de Tordesillas y su época. Congreso Internacional de Historia, Madrid, 1995, pp. 113-135; "The urban oligarchy's affairs in the Government of Castilian Towns in the Late Middle Ages", en M. Boone y P. Stabel (eds.). Shaping urban identity in Late Medieval Europe, 2000, pp. 255-267; "La identidad urbana a finales de la Edad Media", Anales de Historia Medieval de la Europa atlántica, 1 (2006), pp. 5-28. Desde la publicación de su tesis El sistema político concejil: el ejemplo del señorio medieval de Alba de Tormes y su concejo de villa y tierra, (Salamanca, 1988), J.M. Monsalvo ha seguido como una de sus principales líneas de investigación el estudio de las sociedades urbanas medievales y el análisis de las identidades de los grupos que operaban en las ciudades y villas durante este período. Con artículos como "Poder político y aparatos de estado en la Castilla bajomedieval: consideraciones sobre su problemática”, Studia histórica. Historia medieval, 4 (1986), pp. 101-169; "El reclutamiento del personal político concejil: la designación de corregidores, alcaldes y alguaciles en un concejo del siglo XV", Studia histórica. Historia medieval, 5 (1987), pp. 173-196; "Parentesco y sistema concejil: observaciones sobre la funcionalidad política de los linajes urbanos en Castilla y León (siglos XIII-XV)", Hispania: Revista española de Historia, vol. LIII, 185 (1993), pp. 937-969; "Los espacios de poder en la ciudad medieval: impresiones a partir de cuatro casos: León, Burgos, Ávila y Salamanca", en J.I. de la Iglesia Duarte y J.L. Martín Rodríguez (coords.). Los espacios de poder en la España medieval: XII Semana de estudios medievales, Nájera, del 30 de julio al 3 de agosto de 2001, Logroño, 2002, pp. 97-147; "Gobierno municipal, poderes urbanos y toma de decisiones en los concejos castellanos bajomedievales (consideraciones a partir de concejo salmantinos y abulenses)", en Las sociedades urbanas en la España medieval. XXIX Semana de Estudios Medievales, Estella, 15 a 19 de julio de 2002, Pamplona, 2003, pp. 409-488; o la reciente coordinación del libro, Sociedades urbanas y culturas políticas en la Baja Edad Media castellana, (Salamanca, 2013), este autor ha estudiado diversos aspectos del poder político municipal en la Edad Media. Finalmente, J.A. Jara, quien ha centrado su análisis principalmente en el espacio conquense, ha contribuido en esta cuestión con obras como Concejo, poder y élites: la clase dominante de Cuenca en el siglo XV, (Madrid, 2000); "Élites urbanas y sistemas concejiles: una propuesta teórico-metodológica para el análisis de los subsistemas de poder en los concejos castellanos de la Baja Edad Media", Hispania, Revista Española de Historia, LXI/1, núm. 207 (2001), pp. 221-266; "Estructuras formales de poder y de organización de las clases 
reconstruir la trayectoria profesional de los principales agentes que operaban en el ámbito financiero ${ }^{3}$, gracias a lo cual se ha podido iniciar un nuevo modelo de análisis, en el que predomina una visión social de la fiscalidad, especialmente con la reconstrucción de las carreras socio-profesionales de los hombres de negocios que desarrollaron sus actividades en la Castilla bajomedieval. Esta nueva visión de la fiscalidad supone un avance más en los estudios que abordaban la cuestión hacendística, tanto regia como urbana, que, desde la década de los setenta del siglo pasado, se habían centrado en aspectos institucionales y de funcionamiento y composición de los organismos que permitían la articulación del entramado financiero en Castilla, especialmente en los últimos siglos del medievo.

El papel que las ciudades y villas castellanas tuvieron en el modelo fiscal que se fue desarrollando en la Castilla bajomedieval es de sobra conocido. Los monarcas articularon su aparato de recaudación, especialmente en lo referente a impues-

dominantes urbanas en Castilla: el regimiento; una crisis del siglo XIV en el siglo XV, Edad Media: revista de historia, 8 (2007), pp. 225-241; Percepción de «si», percepción del «otro»: la construcción de identidades políticas urbanas en Castilla (el concejo de Cuenca en el siglo XV), Anuario de Estudios Medievales, 40/1 (2010), pp. 75-92; o "Por el conosçimiento que de él se ha". Identificar, designar, atribuir: la construcción de identidades (políticas) en Cuenca en el siglo XV", Hispania: revista española de historia, vol. LXXI, núm. 238 (2011), pp. 389-408.

3. Una primera aproximación al tema fue la de A. Mackay. "Documentos para la historia de los financieros castellanos de la Baja Edad Media. I: una "información” del 23 de septiembre de 1466", Historia, Instituciones, Documentos, 5 (1978), pp. 321-328. Pero los principales esfuerzos se han centrado en el análisis de estas actuaciones a finales del siglo XV y principios del siglo XVI. Así, cabe destacar las numerosas publicaciones en torno a la compañía formada por A. Seneor, R. Mayr Melamed y Luis de Alcalá: C. Álvarez. "Los judíos y la hacienda real bajo el reinado de los Reyes Católicos. Una compañía de arrendadores de rentas reales", en Las Tres Culturas en la Corona de Castilla y los sefardies, Salamanca, 1990, pp. 87-125; Y. Moreno. "Diez años de actividad económica en el reinado de los Reyes Católicos: Rabí Meir Melamed (Fernán Núñez Coronel)”, en A. Meyuhas Ginio y C. Carrete Parrondo (coords.). Creencias y Culturas, Salamanca, 1998, pp. 159-168; M.A. Ladero. "La receptoría y pagaduría general de la Hacienda regia castellana entre 1491 y 1494: de Rabí Meír Melamed a Fernán Núñez Coronel”, En la España Medieval, 25 (2002), pp. 425-506; E. Peña. "Firmas y rúbricas de judeoconversos de la compañía de arrendadores Coronel-Alcalá", Seferad, 71/1 (2011), pp. 201-208; y del mismo autor, "Las propiedades rústicas de una familia de conversos segovianos: los Seneor/Coronel”, Espacio, Tiempo y Forma, Serie III, Historia Medieval, 24 (2011), pp. 319-352; P. Ortego. "Auge y caída de una gran compañía financiera en Castilla: Luis de Alcalá, Rabí Mayr y la quiebra de la receptoría y pagaduría general de rentas (1477-1495)", en E. García Fernández e I. Vítores Casado. Tesoreros, "arrendadores" y financieros en los reinos hispánicos: la Corona de Castilla y el reino de Navarra (siglos XIV-XVII), Madrid, Instituto de Estudios Fiscales, 2012, pp. 101-122. Tampoco debemos olvidar las investigaciones sobre la familia de la Fuente, financieros toledanos de principios del siglo XVI: D. Alonso, "Entre Granada y Castilla. La familia Fuente y la hacienda real a comienzos de la Edad Moderna", Investigaciones históricas: época moderna y contemporánea, 25 (2005), pp. 11-30; M.P. Rabadé. "El proceso inquisitorial contra Fernando de la Fuente, veterano de la guerra de Granada (1505-1506), en M.I. del Val Valdivieso y P. Martínez Sopena (coords.). Castilla y el mundo feudal. Homenaje al profesor Julio Valdeón, Valladolid, 2009, vol. II,", pp. 319-332. Además, D. Alonso García ha publicado otros trabajos en los que analiza la gestión que realizaron diversos grupos financieros que operaron en la hacienda castellana durante el primer cuarto del siglo XVI: "Poder financiero y arrendadores de rentas reales en Castilla a principios de la Edad Moderna", Cuadernos de Historia Moderna, 31 (2006), pp. 117-138; "Capital privado y fiscalidad regia en Castilla a comienzos de la Edad Moderna", en La fiscalità nell'economia europea secc. XIII-XVIII, Florencia, 2008, vol. II, pp. 793-800; "Notas sobre la cooperación en el arrendamiento de rentas reales (1500-1525)", en $I X$ Congreso Internacional de la Asociación Española de Historia Económica, Murcia, 2008, pp. 1-26. 
tos directos, sobre la base y con la ayuda de las ciudades. Los grupos dirigentes de las mismas fueron los encargados de gestionar el reparto de este tipo de fiscalidad directa a través de la elaboración de padrones de vecinos sirviéndose de los empadronadores, vecinos de la propia ciudad, generalmente nombrados por el propio regimiento. El sistema era el mismo en el caso de las imposiciones directas de la fiscalidad concejil. En cuanto a la fiscalidad indirecta, se generalizó la recaudación vía arrendamiento. Aun así, los concejos siguieron desempeñando un papel muy activo, puesto que el entendimiento entre arrendadores y recaudadores regios y los regimientos facilitaba la labor de los primeros.

Como podemos comprobar, el mundo urbano mantuvo una estrecha relación con el entramado físcal. El poder político de los concejos tuvo acceso y control de los resortes fiscales, manipulándolos, en caso de que fuera necesario, en su propio beneficio. Pero también contamos con ejemplos que operaron en dirección opuesta: individuos que, gracias a su actuación como gestores fiscales, no solo construyeron extensos patrimonios personales sino que también obtuvieron mercedes y privilegios que les permitieron acceder a regidurías y otros oficios concejiles ${ }^{4}$.

Nuestra propuesta de análisis se inserta, principalmente, en esa nueva línea de estudio centrada en el aspecto social de la fiscalidad. El objetivo de estas páginas es la reconstrucción de la carrera de Ruy García de la Rúa. Este vecino y regidor de Talavera de la Reina, concejo de señorío del arzobispo de Toledo desde 1369, desarrolló una importante actividad política y económica en este marco territorial desde mediados del Cuatrocientos, cuyo reflejo ha quedado documentado en diversas fuentes de índole municipal así como en registros emitidos por instituciones dependientes del aparato monárquico, especialmente de carácter hacendístico, tales como las contadurías mayores, de rentas y de hacienda.

El estudio de estos individuos y, en mayor profundidad, de las familias en las que estaban insertos, ayuda a la reconstrucción de las sociedades medievales $\mathrm{y}$, en cierta medida, a completar el conocimiento de las mismas. Los oficios que ostentaron o los negocios que emprendieron respondían a una estrategia orientada a la obtención de un fin concreto, que será diferente dependiendo del sujeto. El análisis de las actividades que desarrollaron, de las relaciones que mantuvieron se presenta, por lo tanto, como una oportunidad con la que acercarnos, a través de la óptica de algunos de sus protagonistas, a la sociedad de la época ${ }^{5}$.

El caso de Ruy García de la Rúa y, por extensión de su familia, se presenta como un modelo de estudio que permite completar nuestro conocimiento sobre el sistema social y entramado de relaciones del marco urbano talaverano. Como tendremos ocasión de analizar, su figura se presenta, en primer lugar, como un

4. El caso paradigmático es el de Fernán Pérez Coronel y su yerno Fernán Núñez Coronel, cuyo nombre judío era Abraham Seneor y Rabí Mayr Melamed, respectivamente, convertidos el 15 de junio de 1492 en Guadalupe, quienes recibieron de los reyes sendas regidurías en Segovia, además del nombramiento de Fernán Pérez Coronel como miembro del Consejo Real y contador mayor de las cuentas del príncipe don Juan. M.A. Ladero Quesada. La receptoría y pagaduría general de la Hacienda regia castellana, pp. 433-434.

5. F.J. Fornell Fernández. Linajes gaditanos en la Baja Edad Media. Breve estudio de la oligarquía local (siglos XIII-XV). Cádiz, 2010, p. 15. 
paradigma de ascenso social como gratificación por los servicios prestados a la nobleza, el linaje Vázquez de Acuña en este caso. Además, Ruy García ocupó una de las posiciones centrales en la compleja red de relaciones de carácter financiero construida por y junto a su hermano Juan García de la Rúa, uno de los principales hombres de negocios especializados en la gestión de rentas regias de los arcedianazgos de Toledo y Talavera, principalmente. Finalmente, si extendemos nuestro interés al resto de componentes de la familia García de la Rúa, encontramos que los miembros de este linaje, dada su situación como parte del grupo dominante en el marco urbano, ostentaron una serie de oficios concejiles que les situaron, hasta el nombramiento de Ruy como regidor en 1456, en la órbita del centro de poder político de la villa, el regimiento.

\section{LA FAMILIA GARCÍA DE LA RÚA}

A mediados del siglo XV, los García de la Rúa era una familia integrada en el grupo dirigente urbano. Hasta las primeras décadas del Cuatrocientos carecemos de información sobre ellos. Aunque no pertenecían a ningún linaje de la nobleza local, poseían numerosas propiedades en la villa y su alfoz y tenían acceso a ciertos resortes de poder. Siguiendo el modelo propuesto por el profesor Jara Fuente, quien, en sus estudios sobre élites urbanas distingue dentro de la clase dominante tres segmentos de clase, a saber, élite de poder, élite de participación y resto de cuantiosos o segmento bisagra ${ }^{6}$, creemos conveniente enmarcar, hasta 1456, a la familia García de la Rúa dentro del segundo de estos grupos. Según su definición, la élite de participación viene constituida por:

Los linajes que, sin llegar a acceder al control sobre el acceso a los recursos, han mostrado una especial capacidad para posicionarse en forma privilegiada en los distintos espacios de aprovechamiento de aquéllos ${ }^{7}$.

Esta noción de «acceso a los recursos», resulta imprescindible en la justificación de la inclusión de esta familia como parte de la élite de participación. Siguiendo nuevamente la teoría de Jara Fuente, los linajes pertenecientes a este segmento de clase, y los García de la Rúa no fueron una excepción, desarrollaron una estrategia sustentada en la distribución del poder y control de las demandas sociales de sus miembros, ya que la no satisfacción de las expectativas de uno de ellos podía provocar conflictos en el seno del linaje ${ }^{8}$. En este caso, la política familiar de los García de la Rúa, estuvo orientada al posicionamiento de sus miembros como entes visibles en las diferentes esferas de poder. La dirección de la trayectoria

6. J.A. Jara Fuente. Elites urbanas y sistemas concejiles, p. 256.

7. Ibidem.

8. J.A. Jara Fuente. "Attributing social fields and satisfying social expectations: the urban system as a circuit of power-structuring relations in Castile in the fifteenth century", Oligarchy and patronage in late medieval Spanish urban society, 2009, p. 108. 
socio-profesional de cada uno de los hermanos, siguió como principal premisa la obtención del reconocimiento social de su posición y, en la medida de lo posible, su vinculación con linajes pertenecientes a la élite de poder en pos de adquirir el mayor beneficio y la posibilidad de mantenerse en la órbita de los centros de toma de decisiones e, incluso, mejorar su situación en el entramado social.

En primer lugar, cabe destacar la actuación de uno de los miembros de la familia, el mayor de los hermanos, Fernán García de la Rúa, bachiller en leyes, como letrado del concejo talaverano a mediados del siglo XV. La ostentación de este oficio se presenta como un ejemplo de la situación vivida por miembros de la élite de participación, puesto que le posicionó en torno al regimiento, permitiéndole acercarse al núcleo de poder talaverano y acceder a ciertos beneficios que el cargo le facilitaba, pero no llegó a controlar directamente los recursos concejiles.

Sabemos que ya a finales de la década de 1430 ejercía como bachiller en leyes al servicio de instituciones eclesiásticas tan poderosas como eran la iglesia colegial de santa María de Talavera de la Reina y la propia mesa arzobispal de Toledo. En la apelación a la sentencia pronunciada por el obispo de Jaén en el pleito mantenido por ambas entidades, encabezadas por el propio arzobispo, don Juan de Cerezuela, y el deán de la colegiata, Alfonso Martínez de Logrosán, con Diego García de Toledo, señor de Mejorada, por el aprovechamiento de los montes situados entre las jurisdicciones de Talavera y Mejorada, el bachiller Fernán García actuó en nombre de los eclesiásticos presentando dicha apelación, arguyendo ciertas razones que, a su juicio, invalidaban la sentencia pronunciada ${ }^{9}$. Aunque la petición del bachiller no fue aceptada, alegándose que los argumentos esgrimidos no eran suficientes, esta actuación de Fernán García al servicio del prelado toledano y de la iglesia colegial de Talavera, una de las instituciones más poderosas de la villa, nos da muestra de la confianza vertida en el bachiller de la Rúa.

En la sesión de ayuntamiento del 21 de mayo de 1451, fue nombrado letrado del concejo ${ }^{10}$. En su relación con el regimiento talaverano se han documentado ciertas desavenencias, especialmente desde 1454, cuando fue apartado del cargo, sustituyéndole en dicho oficio el bachiller Juan Guillén ${ }^{11}$. En esa misma sesión, los regidores también revocaban la licencia y merced que habían dado a Fernán para poblar un suelo en la villa ${ }^{12}$. En abril, en respuesta a una carta del bachiller de la Rúa, en la que probablemente pedía la restitución en el oficio o la renovación del mismo, dijeron que les no había menester, ni le tienen por letrado del concejo por cuanto él lo hubo respondido asi $i^{13}$.

Las razones que propiciaron este cambio en su relación con el poder talaverano nos son desconocidas. No fue hasta 1458, dos años después del nombramiento de

9. AMT, Jurisdicción, 1010, Expediente 6.

10. AMT, LLAA 1450-1459, f. 59r.

11. AMT, LLAA 1450-1459, f. 108r. El bachiller Juan Guillén fue renovado en el cargo anualmente hasta 1459, manteniendo los 1.500 maravedíes que recibía, por tercios, como salario por desempeñar este oficio.

12. AMT, LLAA 1450-1459, f. 108r.

13. AMT, LLAA $1450-1459$, f. $114 \mathrm{v}$. 
su hermano Ruy García como regidor, cuando reaparezca en la vida pública de la villa. La influencia que Ruy iba adquiriendo como miembro del cabildo talaverano comenzaba a repercutir positivamente en los miembros de su familia. En la sesión celebrada el 27 de abril de dicho año, cuyo principal objetivo era acordar con los cuantiosos de la villa el reparto de una derrama extraordinaria para la construcción de la obra del puente, diputaron a Fernán García para hacer el repartimiento de dicha derrama ${ }^{14}$. En enero de 1459, tenemos referencia de su comisión como juez, junto al bachiller Juan Guillén, en un pleito que mantenía la villa con Juan de Ayala, señor de Cebolla, por la posesión de las heredades de Baharil y Santos con el Losar, que la villa reclamaba como alijares y Ayala como suyas ${ }^{15}$.

La política familiar de diversificación en las actividades de los distintos miembros del linaje, condujo a que otro de los hermanos García de la Rúa, Juan, centrase sus negocios en el ámbito fiscal. El financiero, fue capaz de posicionarse como uno de los principales gestores de la recaudación de impuestos regios en los arcedianazgos de Talavera y Toledo, principalmente, durante el tercer cuarto del siglo XV. Sus actividades aparecen por primera vez documentadas en 1443, año en el que presentó, junto a García de Alcaraz, vecino de Cuenca, una postura para sanear las rentas del arcedianazgo de Talavera de 1444 con los precios pagados en $1440^{16}$. Desde ese momento hasta sus últimos arrendamientos de alcabalas y servicios de Cortes de 1468, Juan García no sólo se encargó de la recaudación de las rentas regias del arcedianazgo de Talavera, sino que también gestionó la fiscalidad de los arcedianazgos de Toledo y Calatrava y priorazgo de san Juan, contando en algunas de sus operaciones con la colaboración de importantes y conocidos financieros del ámbito toledano, como los hermanos González de San Martín o la compañía formada por Alfonso Sánchez de Aguilar y Gonzalo Rodríguez de Úbeda.

Por su parte, Ruy García de la Rúa dirigió sus actividades hacia una tercera dirección, algo más compleja que en los casos de sus dos hermanos, puesto que, hasta su nombramiento como regidor, combinó su oficio como escribano de cámara, principalmente al servicio del conde de Buendía, Pedro de Acuña, con ciertas incursiones en el mundo financiero de la mano de su hermano Juan y de ciertos socios de éste, como Ruy González de San Martín. Su vinculación con Pedro de Acuña $^{17}$, hermano del arzobispo Alfonso Carrillo, le valió su paso y estancia en la

14. AMT, LLAA 1450-1459, f. 228r.

15. AMT, LLAA $1450-1459$, f. $269 \mathrm{v}$.

16. AGS, EMR, legajo 2, ff. 621r-622v. Tras varias pujas, la renta quedó rematada finalmente en Alfonso García de Illescas, vecino de San Martín de Valdeiglesias.

17. Pedro de Acuña era el primogénito de Lope Vázquez de Acuña, primer señor de Buendía y Azañón, de quien heredó el señorío de Buendía, y de Teresa Carrillo de Albornoz. Por lo tanto, era hermano, entre otros, de Alonso Carrillo, arzobispo de Toledo. En 1439, Juan II le hizo merced del señorío de Dueñas y otras villas en la merindad de Cerrato. El 9 de junio de 1465, a instancias de Alonso Carrillo, recibió de manos de Alfonso XII el único título de nobleza que concedió el monarca, el de conde de Buendía. Tras la muerte de éste en 1468, Enrique IV no confirmó la merced. Tuvo que esperar hasta la llegada al trono de Isabel I para recuperar el título de conde que había obtenido diez años antes. F. Layna Serrano. Historia de Cifiuentes. Guadalajara, 1979, p. 94; J.I. Ortega Cervigón. "El arraigo de los linajes portugueses en la Castilla bajomedieval: el caso de los Acuña en el obispado de Cuenca", Medievalismo: Boletín de la Sociedad Española de Estudios Medievales, 16 (2006), pp. 76-77; 
corte, donde se encargaba de los asuntos y negocios del conde. Gracias a su relación con el linaje Acuña, y como recompensa a los servicios que les había prestado, el prelado toledano, señor de Talavera de la Reina, le hizo merced en 1456 de la regiduría que había quedado vacante en el cabildo talaverano, por el fallecimiento de Francisco Ortiz. A partir de este momento, sus negocios se centraron en el marco urbano de la villa, aunque no abandonó por completo, como tendremos ocasión de comprobar, su presencia en el ámbito financiero, manteniendo su papel como uno de los principales fiadores en los arrendamientos de su hermano Juan. La relación de Ruy García con el arzobispo Carrillo y el linaje Acuña se perpetuó a través del casamiento de la hija del regidor, Elvira de la Rúa, con Francisco de Cienfuegos, criado del prelado, quien también recibió la merced de una regiduría en Talavera.

Finalmente, hemos podido documentar, gracias a la nómina de fiadores presentada por Juan García en la puja antes mencionada de 1443, la existencia de un cuarto hermano, Diego, aunque carecemos de cualquier otra información sobre él ${ }^{18}$.

Como se puede observar, cada uno de ellos orientó sus actividades hacia un campo diferente cumpliendo, en cierta manera, ese afán de los miembros de los linajes de la élite de participación de diversificar sus operaciones y estar presente en diversos ámbitos para poder posicionarse, de este modo, cerca de los núcleos de poder, tanto políticos como económicos. El oficio desempeñado por Juan García se diferenciaba notablemente del ostentado por sus hermanos Fernán y Ruy, no sólo en lo referente a la propia actividad inherente a los cargos, sino también en relación a ciertas cuestiones que rodeaban a los mismos, tales como la vecindad, el número de contactos activos o la orientación de las expectativas y los objetivos finales de sus actividades.

De esta manera, una de las principales diferencias entre los hermanos es la referente a la movilidad geográfica. Mientras Fernán y Ruy mantuvieron su condición de vecinos talaveranos (aunque este último aparece como morador de Toledo en ciertas ocasiones puntuales, debido, probablemente al cargo de juez de la fieldad de la ciudad que desempeñó durante un tiempo ${ }^{19}$ ), encontramos que Juan,

y D.C. Morales Muñiz. "La concesión del título de (I) conde de Buendía por el rey Alfonso XII de Castilla (1465) como expresión del poder del linaje Acuña”, Espacio, Tiempo y Forma. Serie III. Historia Medieval, 19 (2007), pp. 202-210.

18. AGS, EMR, legajo 2, ff. 621r-622v. Es plausible que el mismo Diego García de la Rúa, escribano, al que la documentación hace referencia como poseedor de las heredades de Torrecilla y Valdefuentes, que posteriormente se documentan como patrimonio de Ruy García de la Rúa. J. Gómez-Menor. La antigua tierra de Talavera. Bosquejo histórico y aportación documental. Toledo, 1965 , p. 69.

19. El juez de la fieldad de Toledo era un oficio municipal que se encargaba de resolver las quejas de los habitantes de la zona rural de los montes al sur de la urbe, pertenecientes a la ciudad. En principio el encargado era uno de los regidores toledanos, elegido cada tres años. Con el ascenso al trono de Juan II, el monarca comienza a concederlo en merced. Así ocurrió, entre otros, con Ruy García de la Rúa. Ya durante el reinado de Enrique IV, el enfrentamiento de Ruy con el regimiento toledano provocó que éstos votasen para privarle del oficio. A pesar de que Alfonso XII le devolvió el oficio durante un breve espacio de tiempo, y aunque pleiteó intensamente para recuperarlo, desde 1459, año 
siguiendo la tendencia que también se observa al analizar las trayectorias de otros financieros de la época, cambió de vecindad hasta en tres ocasiones. Esta característica movilidad geográfica que se observa en numerosos ejemplos de hombres de negocios bajomedievales, está relacionada con la búsqueda de las condiciones más ventajosas para sus operaciones. En el caso de Juan García, hemos documentado su avecindamiento en Talavera, Toledo y Ocaña, villa esta última en la que se estableció finalmente desde 1455. El traslado de un lugar a otro condicionó, en parte, sus negocios, puesto que se ha observado que con cada cambio de vecindad, variaba la nómina de fiadores presentada como garantes de sus operaciones financieras, sustituyendo a moradores de las ciudades que dejaba por convecinos del nuevo lugar donde habitaba. En este listado de avalistas, e independientemente de la vecindad de Juan, únicamente se mantienen los nombres de sus hermanos Fernán y Ruy. Este hecho confirma, por una parte, la solidez de sus vínculos, la noción de pertenencia a un mismo grupo familiar y el soporte proporcionado por el linaje a sus miembros; y, por otra, la importancia del parentesco y, de nuevo, el respaldo familiar, especialmente el de hermanos, en las operaciones financieras de los hombres de negocios bajomedievales ${ }^{20}$.

Todo ello nos pone en relación con otra de las cuestiones planteadas. Así, cabe señalar la diferencia entre los hermanos en cuanto al número y variedad de contactos activos, es decir, las personas con las que existe reconocimiento y accesibilidad mutua $^{21}$. Por el carácter de su oficio, más centrado en el marco urbano talaverano, la red de relaciones de Fernán García de la Rúa estuvo focalizada en dicho ámbito, lo que no excluye que mantuviera ciertos vínculos con personas externas al concejo, aunque su número no alcanzaría al de las conexiones que estableció su hermano con individuos de un amplio espacio geográfico. En los casos de Juan y Ruy encontramos una situación diferente. Como hemos indicado, con cada cambio en su lugar de residencia, aparecen nuevos nombres en el listado de avalistas de las operaciones del financiero. Esta situación facilitó que aumentase paulatinamente el número de personas con las que mantenía vinculación de diversa naturaleza. En cuanto a Ruy, su oficio como escribano de cámara, sus incursiones en el ámbito financiero y su servicio al conde de Buendía, le llevó a relacionarse con una amplia gama de individuos que se movían en esferas muy diferentes.

Las relaciones que fueron construyendo y manteniendo en distintos círculos así como las actividades que desarrollaron en diferentes ámbitos y entramados sociales en los que se movieron, $y$, en definitiva, la estrategia seguida por cada uno de ellos, estuvieron destinadas a la consecución última de unos objetivos, diferentes en cada caso. Mientras Fernán y Ruy mantuvieron, especialmente el

en el que fue privado del mismo, no volvió a ejercerlo. O. López, Violencia urbana y paz regia: el fin de la época medieval en Toledo (1465-1522), Tesis doctoral inédita, 2006 pp. 917-919.

20. D. Alonso García. "Notas sobre la cooperación en el arrendamiento de rentas reales (15001525)", IX Congreso Internacional de la Asociación Española de Historia Económica, Murcia, 2008 (http://www.um.es/ixcongresoaehe/pdfB2/Notas\%20sobre.pdf), pp. 1-26.

21. J.L. Molina González. "El estudio de las redes personales: contribuciones, métodos y perspectivas", Empiria. Revista de metodología de Ciencias sociales, 10 (2005), pp. 71-105. 
primero de ellos, como su marco de actuación el concejo talaverano, Juan centró su atención en el mundo de la fiscalidad, lo que le condujo, como hemos indicado, a abandonar su localidad de origen para establecer como centro de sus operaciones otros lugares, primero Toledo y, posteriormente, Ocaña. La lejanía geográfica del financiero con respecto al núcleo familiar y territorial de su linaje, conllevó el deterioro paulatino de su relación con sus parientes. Desde 1468, último año en el que Ruy afianzó a su hermano, carecemos de información sobre la vinculación de Juan con el resto de miembros del linaje García de la Rúa ni con Talavera. No ocurrió lo mismo con los descendientes de Ruy y Fernán, puesto que la documentación nos muestra cómo gran parte de ellos desarrollaron sus actividades en el ámbito talaverano.

Los hijos de Fernán pudieron beneficiarse del acceso de su tío Ruy a la regiduría talaverana, ostentando tres de ellos, Gutierre, García y Francisco, el oficio escribanos públicos del número de la villa, cargo que, según la donación de Talavera al arzobispo Gómez Manrique, correspondía designar al prelado toledano entre los vecinos de la villa, en ejercicio de sus facultades señoriales sobre la villa, aunque, en las décadas finales del Medievo, el nombramiento de los mismos era un proceso compartido entre regimiento y señor, proponiendo los primeros el nombre del candidato que, a su juicio, resultaba más idóneo, limitándose el segundo a ratificar o rechazar la propuesta. Aunque tenemos noticia de la actuación de todos ellos en el oficio de escribanía, fue Gutierre quien tuvo una mayor presencia en la vida pública del concejo, encargándose de las más diversas cuestiones, entre otros, dar fe en la compra-venta de heredades entre vecinos de Talavera ${ }^{22}$, en la fundación de la capellanía del señor de Cebolla, Juan de Ayala en $1485^{23}$, o la gestión del arrendamiento por menor de las alcabalas cobradas en la villa ${ }^{24}$.

Rodrigo de la Rúa, también hijo de Fernán García, sufrió una suerte diferente. Entró al servicio de Diego López de Ayala, capitán de la reina Isabel, quien tomó Talavera de la Reina en 1478 ante la sublevación del señor de la villa, el arzobispo Alonso Carrillo. Rodrigo de la Rúa participó en esta operación militar, por lo que recibió como gratificación de manos de los monarcas católicos 8.000 maravedíes anuales de juro de heredad situados en la alcabala del pan en grano de Talavera ${ }^{25}$. La relación entre Rodrigo de la Rúa y Diego López de Ayala, hijo del regidor talaverano y señor de Cebolla Juan de Ayala, pudo haber sido facilitada por la posición de esta familia en el entramado sociopolítico del concejo.

22. SNAHN, Bornos, carpeta 790, documentos 85-86.

23. SNAHN, Frías, Carpeta 1318, documento 3b.

24. AGS, Expedientes de Hacienda, legajo 16, ff. 57-70.

25. AGS, EMR, legajo 36, f. 125. 


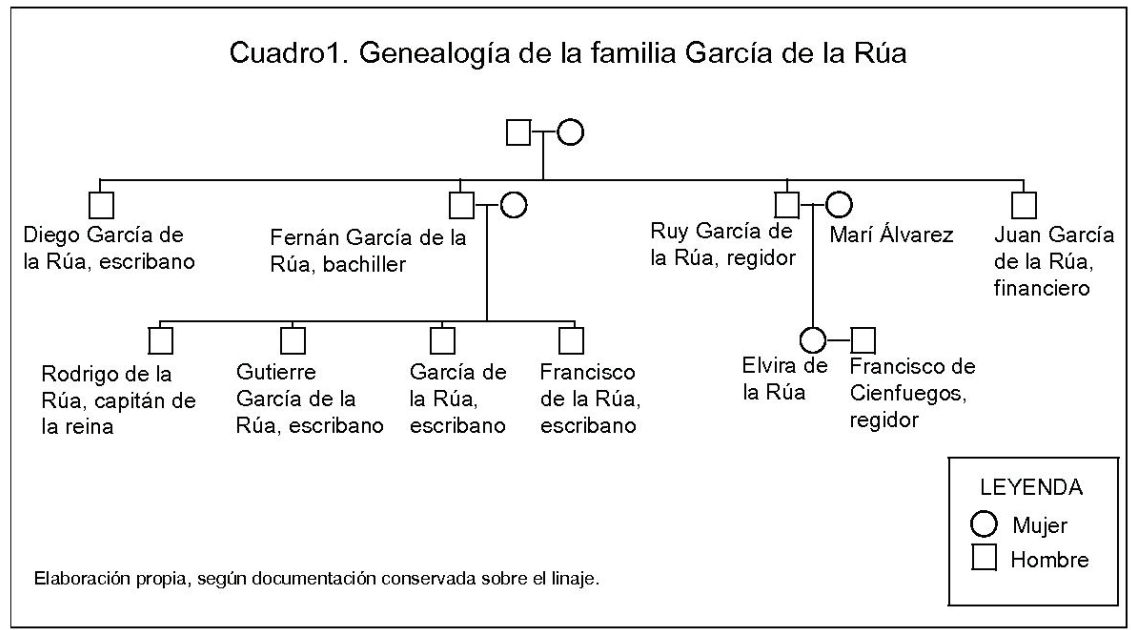

Como se puede observar, estos miembros del linaje de la Rúa lograron posicionarse cerca del centro del poder talaverano, manteniendo su condición de élite de participación. No es que supusiera su retroceso en la escala social, sino que fue Francisco de Cienfuegos, quien ostentó otra de las regidurías, al igual que su suegro, gracias a la merced que de ella le hizo el arzobispo Carrillo.

\section{Actividades DeSARrolladas EN El Ámbito FinANCIERO}

Desde inicios de la década de 1440, encontramos a Ruy García de la Rúa vinculado a la gestión de los impuestos regios. Sus actividades en este ámbito se desarrollaron en torno a dos ejes: el arrendamiento y recaudación de las rentas y su presencia como fiador en los negocios de su hermano, Juan García, y los socios de este.

En su faceta como arrendador, estuvo interesado en la gestión de dos rentas: los servicios de Cortes, especialmente el cobro de las monedas que se cargaban junto al pedido, y las albaquías. Su preferencia hacia el manejo de la percepción de las monedas se debió, probablemente, a la mayor sencillez del proceso recaudatorio. A diferencia de lo que ocurría en otros impuestos, como el pedido o las alcabalas, la cuantía que se debía cobrar en concepto de monedas se calculaba en base a un canon ya fijado, por el que una moneda equivalía en Castilla, las Extremaduras y la frontera a ocho maravedíes, y a seis en León. Por lo tanto, los recursos necesarios para percibir este impuesto eran menores a los requeridos para el pedido, más difícil de cobrar, y el que se necesitaba la colaboración y entendimiento con las autoridades locales, así como el envío de factores que supervisasen el proceso y comprobasen que la labor de empadronadores y cogedores se había realizado correctamente. 
Como se puede observar en la tabla 1, la primera aparición documentada en el arrendamiento de rentas regias de Ruy García de la Rúa data de 1442. Este año, lo encontramos como arrendador mayor en las segundas 15 monedas y en el pedido del arcedianazgo de Talavera ${ }^{26}$, junto a Ruy González de San Martín, quien actuó como recaudador mayor del impuesto ${ }^{27}$; y como arrendador mayor de esta misma renta del arcedianazgo de Madrid, quedando como recaudador mayor el hermano de Ruy González, Pedro González de San Martín ${ }^{28}$. Desde este momento, la cooperación entre ambas familias fue un hecho constatado, especialmente en los casos de Juan García y Ruy González en la gestión de diferentes rentas regias de los arcedianazgos de Talavera y Toledo, fundamentalmente en la década de 1450.

Tabla 1. Gestión como arrendador mayor de las monedas de los servicios de Cortes de Ruy García de la Rúa

\begin{tabular}{|c|c|c|c|}
\hline Año & Renta & $\begin{array}{c}\text { Cuantía } \\
\text { (mrs.) }\end{array}$ & Colaboración \\
\hline 1442 & \begin{tabular}{|l|} 
Segundas 15 monedas. \\
Arcedianazgo de Talavera
\end{tabular} & 474.450 & $\begin{array}{l}\text { Ruy González de San Martín, recau- } \\
\text { dador mayor }\end{array}$ \\
\hline 1442 & $\begin{array}{l}\text { Segundas } 15 \text { monedas. } \\
\text { Arcedianazgo Talavera }\end{array}$ & & $\begin{array}{l}\text { Pedro González de San Martín, recau- } \\
\text { dador mayor. Traspasa la renta a Fran- } \\
\text { cisco Fernández de Sevilla }\end{array}$ \\
\hline 1449 & $\begin{array}{l}\text { Primeras } 12 \text { monedas. } \\
\text { Arcedianazgo Toledo }\end{array}$ & 541.250 & Junto a Rodrigo de la Fuente \\
\hline 1449 & \begin{tabular}{|l|} 
Segundas 12 monedas. \\
Arcedianazgo Toledo
\end{tabular} & 541.250 & Junto a Rodrigo de la Fuente \\
\hline 1450 & $\begin{array}{l}4 \text { monedas. } \\
\text { Arcedianazgo Toledo }\end{array}$ & 180.417 & \\
\hline 1451 & $\begin{array}{l}\text { Primeras } 12 \text { monedas. } \\
\text { Arcedianazgo Toledo }\end{array}$ & 541.250 & \\
\hline 1451 & $\begin{array}{l}\text { Segundas } 12 \text { monedas. } \\
\text { Arcedianazgo Toledo }\end{array}$ & 541.250 & \\
\hline $1451-152$ & $\begin{array}{l}\text { Servicio de Cortes. } \\
\text { Arcedianazgo Toledo }\end{array}$ & 405.907 & Junto a Rodrigo de la Fuente \\
\hline 1453 & \begin{tabular}{|l|} 
Monedas. \\
Arcedianazgo Talavera
\end{tabular} & 306.348 & $\begin{array}{l}\text { Traspasa la renta a Pedro González de } \\
\text { Toledo }\end{array}$ \\
\hline
\end{tabular}

26. AGS, EMR, legajo 2, ff. 443r-444v.

27. Ruy González de San Martín ya había actuado como recaudador mayor en la gestión de las 15 primeras monedas del arcedianazgo dicho año, aunque en esa ocasión contó con Juan García de la Rúa como arrendador mayor de la renta. Juan García presentó como sus fiadores a Fernán González de Sevilla y a Juan Álvarez del Pulgar, dejando fuera de sus fianzas a sus hermanos Ruy y Fernando, lo que no se volverá a repetir, especialmente en el caso del primero, hasta el abandono de Juan García del negocio financiero. AGS, EMR, legajo 2, ff. 420r-421v.

28. Según un albalá de Juan II, fechado el 17 de noviembre de 1443, Ruy García traspasó el segundo servicio de dicho año a Francisco Fernández de Sevilla, escribano de cámara del rey, quien más tarde ejerció como escribano de rentas. AGS, Expedientes de Hacienda, leg. 1, f. 15r. 
Igualmente, cabe destacar el arrendamiento conjunto de Ruy García y Rodrigo de la Fuente en los servicios de Cortes del arcedianazgo de Toledo en 1449 y 1451 $1452^{29}$. ¿Quién es y qué conocemos de Rodrigo de la Fuente? Son pocos los datos que se han conservado sobre él. Sabemos que era miembro de una de las familias más importantes en el sector financiero del partido de Toledo, puesto que su padre Alfonso López de la Fuente, fue un importante financiero en la zona en la década de 1440, y además colaboró en distintos negocios con Alfonso Sánchez de Aguilar y Gonzalo Rodríguez de Úbeda, dos potentes gestores de la fiscalidad regia en este período $^{30}$. De la actividad de Rodrigo de la Fuente poco se sabe ${ }^{31}$. Bien porque no continuase con los negocios financieros de su padre y dirigiera sus actividades hacia otros sectores bien porque su intervención en este caso fuera meramente puntual, lo cierto es que, con la salvedad de los dos arrendamientos conjuntos que realizó con Ruy García de la Rúa, y la aparición de su nombre como testigo en la entrega de cartas de bula de cruzada en 1459 a Ruy González de San Martín ${ }^{32}$, carecemos de datos sobre Rodrigo de la Fuente.

Esto nos lleva a plantearnos el porqué de la asociación entre Ruy y Rodrigo. Puesto que ninguno de los dos era núcleo de algún grupo financiero encargado del arrendamiento y/o recaudación de rentas regias, sino que ambos eran familiares de gestores que tenían o iban adquiriendo cierta relevancia en el negocio fiscal en el reino de Toledo, vemos como hipótesis más factible que esta asociación se inscribiera en el conjunto de operaciones realizadas en común por Juan García de la Rúa y los socios de Alfonso López de la Fuente, Gonzalo Rodríguez de Úbeda y Alfonso Sánchez de Aguilar, quienes ya habían traspasado a Juan la mitad del pedido y monedas de $1447^{33}$. Otra posibilidad, aunque la consideramos menos probable, sería que Ruy y Rodrigo quisieran arrendar dichas monedas pero que, ante la carencia de medios para hacerlo en solitario, decidieran asociarse en lugar de pujar individualmente e incrementar el precio de la renta.

Las últimas operaciones relacionadas con la gestión del pedido y monedas realizadas por Ruy García tuvieron lugar a inicios de la década de 1450, cuando

29. AGS, EMR, legajo 8, ff. 676r, 677r y 678r.

30. Las actividades del financiero incluyeron tanto el afianzamiento a otros hombres de negocios en sus operaciones, como los 150.000 maravedíes con los que avaló en 1440 a Juan Ramírez de Toledo (AGS, EMR, legajo 2, f. 26v. y 30 r.); como el arrendamiento, en solitario o en colaboración de algún socio, de ciertas rentas regias, especialmente del arcedianazgo de Toledo. Por ejemplo, en 1447-1448, arrendó el pedido y monedas del arcedianazgo de Toledo (AGS, EMR, legajo 2, f. 469). Además, desde 1448 gestionó junto a Alfonso Sánchez de Aguilar y Gonzalo Rodríguez de Úbeda, entre otras rentas, las alcabalas de Toledo (AGS, EMR, legajo 4, ff. 34-37).

31. No debemos confundir este Rodrigo de la Fuente con su homónimo, padre de Diego de la Fuente, cabeza de la importante compañía de conversos toledanos que centró su negocio a principios del siglo XVI en el arrendamiento de la seda de Granada, principalmente. Para saber más de esta compañía, véase, D. Alonso García. "Entre Granada y Castilla. La familia Fuente”, pp. 11-30.

32. Según el documento, Diego Calderón, en nombre de Ruy González de San Martín, recibió en Arévalo el 31 de agosto de 1459, 414 cartas de bula de Cruzada, firmadas de Juan de Arévalo, secretario del arzobispo. En el acto estuvieron como testigos Fernando González de la Fuente, escribano, Gonzalo de Zalamea y Rodrigo de la Fuente. AGS, EMR, legajo 8, ff. 1038r-1039v.

33. AGS, EMR, legajo 2, f. 482r. 
obtuvo en solitario el remate de los servicios de Cortes del arcedianazgo de Toledo. Cabe destacar la participación de su hermano, Juan García, como recaudador mayor de estas rentas, lo que debe entenderse como parte de su estrategia de negocio: ambos trabajaron conjuntamente para obtener un mayor beneficio de la gestión de dichas rentas ${ }^{34}$.

Mayor interés reviste el remate que obtuvo de las 14 monedas del arcedianazgo de Talavera de 1453. A pesar de quedar como arrendador de las mismas, traspasó la renta por completo a Pedro González de Toledo ${ }^{35}$. Se trataba de una transferencia interesada y enmarcada en la estrategia de negocio seguida por Juan García, puesto que Pedro González era uno de sus principales hombres de confianza, como demuestran las múltiples ocasiones en que actuó en nombre del financiero ante diversos agentes ${ }^{36}$.

Otra de las rentas regias por las que Ruy estuvo interesado fueron las albaquías, de las que fue arrendador de parte de las que se calcularon hasta finales de 1452 . Entre una larga nómina de arrendadores, encontramos a Ruy García, quien se obligó por 993.103 maravedíes ${ }^{37}$. De esa cantidad, 223.000 maravedíes correspondían a las deudas contraídas en el arcedianazgo de Talavera. En principio, la gestión la iba a realizar conjuntamente con Pedro González del Castillo pero, ante la falta de fiadores de éste, Ruy García quedó como único gestor, con 10.000 maravedíes de prometido ${ }^{38}$. Carecemos de la relación de fiadores que presentó para asegurar este arrendamiento e ignoramos los medios que utilizó para ello, lo nos hubiera permitir conocer si utilizaba los mismos recursos que su hermano o había logrado obtener el apoyo de otras personas y establecer su propia red de relaciones.

Dentro del ámbito financiero, cabe destacar la faceta de Ruy García como fiador de las operaciones de Juan García de la Rúa y aquellos con los que éste se asociaba. Desde 1449 hasta 1468 fue habitual la presencia del regidor talavera en el listado de avalistas presentado por el financiero ante los oficiales regios.

34. AGS, EMR, legajo 8, ff. 676r, 677r y 678r.

35. AGS, EMR, legajo 8, ff. 741r-744v. La documentación nombra a este personaje como Pedro González de Zalamea o Pedro González de Toledo refiriéndose, en este último caso, a su avecindamiento en la capital del Tajo.

36. En 1451, se presentó ante los contadores mayores con poder de Juan García para obligarlo al pago de los servicios de 1451 y 1451-1452, de los que era recaudador mayor (AGS, EMR, legajo 4, ff. 30r y 90r-91r. y AGS, EMR, legajo 8, f. 678r). Un año más tarde, solicitó en nombre del financiero la carta de recudimiento para las alcabalas de Toledo de dicho año, ratificando las fianzas que había dado el arrendador para dicha renta un año atrás (AGS, EMR, legajo 4, fols. 381r-382v). El mismo cometido tuvo en 1454, aunque en esta ocasión solicitaba el documento que les permitiera recaudar el pedido y 14 monedas del arcedianazgo de Talavera, del que Juan era arrendador y recaudador mayor (AGS, EMR, legajo 6, ff. 25r-26v). Su presencia en la corte está documentada en una nueva ocasión, cuando requirió el recudimiento de las alcabalas del arcedianazgo de Talavera de 1455 (AGS, EMR, legajo 6, ff. 182r-184v). Como muestra de la confianza depositada en él, Juan García de la Rúa le dio poder para negociar el pago de las alcabalas y servicio de Cortes con el concejo Talavera de la Reina en abril de 1456, donde debió contar con el apoyo de Ruy García, ya nombrado regidor (AMT, LLAA, 1450-1459, f. 177r).

37. AGS, EMR, legajo 7, ff. 60r-63v.

38. AGS, EMR, legajo 8, ff. 157r-158r. 
Como se puede observar en el gráfico 1, las fianzas que Ruy García proporcionaba a su hermano fueron en aumento. Desde los 50.000 maravedíes de 1449, llegó a los 280.000 maravedíes en 1463. La variabilidad de la cuantía con la que afianzaba a Juan y a los compañeros con los que éste operaba, se encuentra en estrecha relación con dos cuestiones: su nombramiento como regidor en 1456, y el volumen de rentas arrendadas por el financiero toledano. Así, hay que entender que el salto cuantitativo que se produce entre 1455 y 1456 está estrechamente relacionado con el momento en el que accede a la regiduría talaverana.

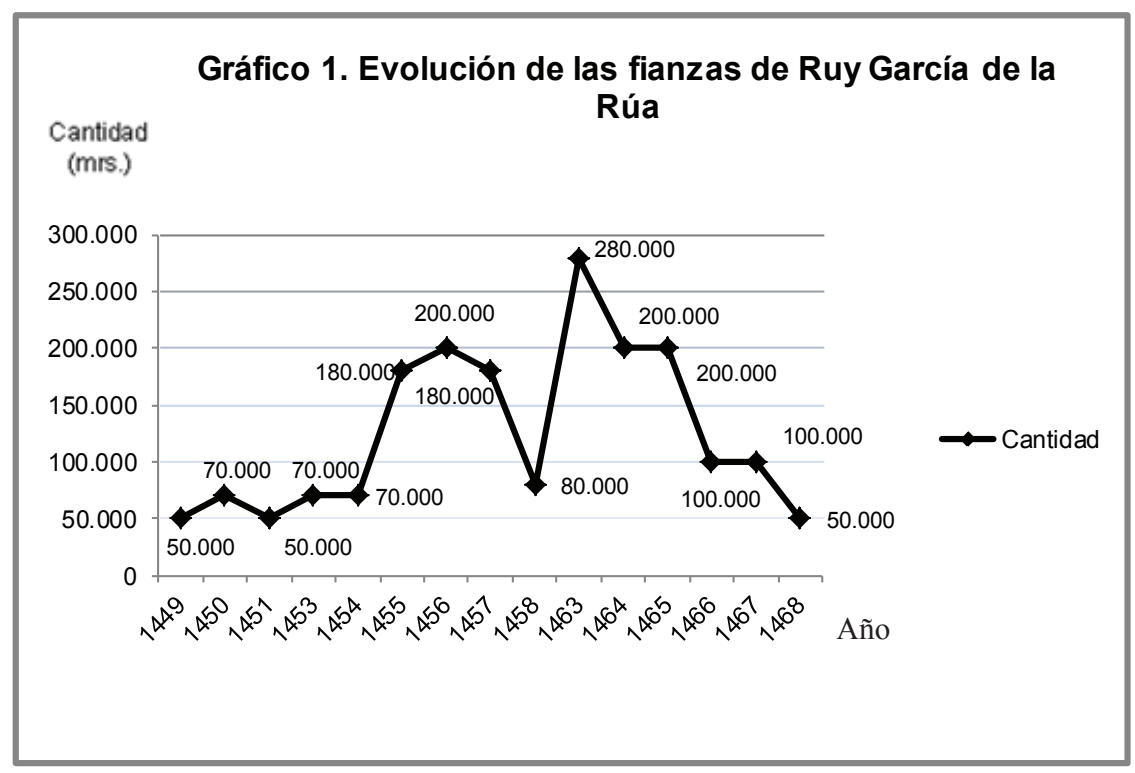

Fuente: AGS, EMR, Legajos 4, 5, 6, 7, 8, 11, 12, 13, 14, 15, 16 y 28/2. Elaboración propia

En segundo lugar, debemos tener en cuenta que la cantidad aportada por Ruy García estuvo condicionada por los arrendamientos de Juan. Teniendo en cuenta esta cuestión, podemos explicar la fuerte caída que se percibe en el gráfico entre 1457 y 1458. Así, en el primero de dichos años, Ruy García fue fiador de Juan García en dos rentas: las alcabalas y tercias de Talavera, por las que otorga fianza por 80.000 maravedíes anuales ${ }^{39}$; y también figura en esa condición en el pedido y monedas de Toledo, del que Juan fue arrendador y recaudador mayor junto a Ruy González de San Martín, renta que aseguró por 100.000 maravedíes ${ }^{40}$. Una vez recaudado el servicio de Cortes, en 1458, el aval de Ruy únicamente se limitó a esos 80.000 maravedíes con los que había afianzado las alcabalas y tercias un año atrás.

39. AGS, EMR, legajo 7, ff. 397r-398v.

40. AGS, EMR, legajo 5, ff. 133r-134v. 
De igual modo se entiende la tendencia continua al descenso en las fianzas en el trienio 1465-1468, especialmente el último año, cuando Juan García únicamente tuvo arrendadas las alcabalas de Toledo ${ }^{41}$.

Como se puede observar, las actividades desarrolladas por Ruy García de la Rúa en el ámbito financiero estuvieron marcadas por la estrategia de negocio de su hermano Juan García, y supeditadas a los intereses del financiero.

\section{Ruy García de la RÚA y la POLÍtica municipal DE TAlaVERA DE LA REINA}

A principios de 1456, fallecía el regidor Francisco Ortiz Calderón. El 6 de febrero de dicho año, Ruy García presentaba ante el regimiento una carta del arzobispo en la que le proveía de la regiduría vacante. Como hemos indicado, esta merced era fruto de la estrecha vinculación y el servicio prestado por el escribano a la familia Acuña. La reacción de los oficiales talaveranos no se hizo esperar. Obedecieron la carta como mandato de su señor pero, alegando la defensa de los usos y costumbres de la villa, y la potestad que tenían de elegir a los nuevos regidores y escribanos, arguyeron que la respuesta tendría que esperar hasta que consultasen con el prelado esta cuestión ${ }^{42}$.

Tras la donación de Talavera de la Reina por Enrique II a Gómez Manrique, arzobispo de Toledo, como agradecimiento a los servicios prestados al Trastámara durante la Guerra Civil ${ }^{43}$, el concejo había negociado con su nuevo señor algunos aspectos concernientes al gobierno municipal. De este modo, en lugar de ofrecer una resistencia frontal a la nueva situación derivada de la decisión del nuevo monarca, los vecinos talaveranos decidieron acordar con el prelado toledano unas capitulaciones en las que procuraron defender y mantener los usos y costumbres de la villa. El arzobispo accedió a mantener la costumbre de los vecinos de designar a los alcaldes, alguacil y escribanos públicos de Talavera, aunque debía ser él quien ratificase la elección ${ }^{44}$.

41. AGS, EMR, legajo 15, f. 402r.

42. AMT, LLAA $1450-1459$, f. 174r.

43. Más que de una donación, se trató de una permuta entre la reina, doña Juana Manuel, y el prelado. Durante la guerra civil Enrique II, probablemente siguiendo el ejemplo de su padre, Alfonso XI, quien cedió Talavera a la reina María de Portugal, donó la villa a su esposa. El 25 de junio de 1369, Enrique II entregó Talavera al arzobispo a cambio del retorno de Alcaraz a la corona (cedida con anterioridad por el Trastámara a Gómez Manrique). Este intercambio respondía a una cuestión estratégica. Aparte de su privilegiado emplazamiento, en el camino hacia el reino de Murcia y la Gobernación de Orihuela, Alcaraz se encontraba cerca de la frontera con Granada. El rey quiso mantener este enclave, con el fin de defender la plaza ante una posible incursión de los granadinos, y para controlar el incipiente tráfico comercial y humano entre la Meseta y la costa. E. Rodríguez-Picavea Mantilla. Origenes y desarrollo de la señorialización en la villa de Talavera y su tierra (siglos XIII$X V)$. Talavera de la Reina, 2007, pp. 47-48.

44. M.J. Suárez Álvarez. La villa de Talavera y su tierra en la Edad Media (1369-1504). Oviedo, 1982, p. 177. Además, accedió a no apoderarse ni administrar los propios, rentas y derechos concejiles, delegando esta cuestión en el gobierno local. También se comprometió a no pedir nuevos 
Los encargados de tratar con Alonso Carrillo la cuestión del nombramiento de Ruy García fueron los regidores Álvaro de Loaísa y Fernando de Talavera, que viajaron a Toledo ex profeso, y Pedro Suárez de Toledo, quien se encontraba en la capital. Tras debatir con el señor sobre ello, finalmente recibieron a Ruy García como regidor el 21 de abril de $1456^{45}$.

La imposición de la voluntad del prelado toledano frente a los usos y costumbres de la villa, no facilitó a Ruy García su inclusión en la vida política urbana. Así, un año después de su nombramiento, en abril de 1457, el regimiento ordenaba al fiel que pagase su salario al nuevo regidor, cantidad que se le debía haber librado por Navidad, como era costumbre en Talavera. Según la documentación municipal, decidieron pagarle con suplicación del arzobispo, apercibiéndole que de aqui adelante si fuera ausente que no se librarán ${ }^{46}$. Este testimonio es revelador. En primer lugar, muestra la tensión entre oficiales concejiles y el nuevo regidor, siendo necesaria, nuevamente, la intercesión de Alonso Carrillo a favor de Ruy García. Además, evidencia el absentismo de nuestro hombre respecto de sus deberes en la villa, probablemente todavía más preocupado, durante estos primeros momentos, por sus actividades en la corte al servicio del señor de Buendía. La cuestión no revestiría mayor importancia, puesto que la ausencia de los regidores en las sesiones de ayuntamiento era frecuente en la Castilla de mediados del Cuatrocientos, si no fuera por la advertencia que le hacen de no pagarle el salario en caso de que no tuviera una presencia más activa, lo que es indicativo del enfrentamiento con el nuevo regidor.

Paulatinamente, Ruy García logró integrarse en la vida municipal talaverana. El hecho de que el cabildo lo comisionase, como al resto de regidores, para encargarse y solventar ciertos asuntos concernientes al concejo, es muestra de ello. $\mathrm{Su}$ actuación fue requerida en cuestiones ordinarias en la vida política del concejo, como la solución de ciertos pleitos entre los habitantes de la tierra, ejerciendo de este modo la potestad judicial que tenía como miembro del cabildo urbano, o la supervisión de algunos asuntos de índole económica, como la averiguación del pago a realizar por servicios prestados a la villa o la fiscalización de las cuentas de los mayordomos concejiles ${ }^{47}$. También lo encontramos presente en otras ocasiones algo más extraordinarias, como la toma de posesión del término cuando se nombraba un nuevo corregidor, acto que simbolizaba la subordinación de los lugares del alfoz a la nueva autoridad municipal, o encargarse, en algunos momentos pun-

tributos y a respetar las costumbres en cuanto al aprovechamiento de pastos y explotación de alijares. La única cuestión a la que se negó fue a la pérdida de la fonsadera. E. Rodríguez-Picavea. Orígenes y desarrollo de la señorialización en la villa de Talavera, pp. 49-50. M.J. Suárez Álvarez. "La expansión del régimen señorial con Enrique de Trastámara: el ejemplo de Talavera de la Reina", En la España Medieval, 7 (1985), p. 1135.

45. AMT, LLAA 1450-1459, f. 178r.

46. AMT, LLAA 1450-1459, f. 225r.

47. AMT, LLAA, 1476-1477, ff. 76v y 79v. 
tuales, de supervisar el pleito que mantenía la villa con ciertos lugares del alfoz por la plantación de viñas ${ }^{48}$.

Quizá el negocio más importante para el que fue comisionado estos años se produjo en 1480, cuando tuvo que defender los intereses de la villa frente a los ataques que Fernando de Monroy, señor de Belvís, Deleitosa y Fresnedosa, y sus vasallos realizaban en la parte noroccidental del término talaverano. En esta ocasión, se presentó en la corte, establecida en Medina del Campo, ante los Reyes Católicos para pedir justicia por los constantes agravios que sufrían por parte de Monroy y sus hombres. Los monarcas delegaron la cuestión en el bachiller Diego de la Torre, vecino de Toledo, y le encomendaron que, tras informarse sobre el asunto y escuchar a las partes, dictase sentencia ${ }^{49}$.

A pesar de la aparente sintonía conseguida entre el nuevo regidor y los oficiales concejiles, en 1468, encontramos el testimonio de Fernando Sánchez de Chozas, en el que asegura que se vio obligado a vender su casa y tierras en el lugar de Carchenilla, término de la villa, bajo coacción a Francisco de Cienfuegos, regidor, yerno de Ruy García. El documento no se ha conservado íntegramente, pero en este fragmento de declaración, Fernando Sánchez relata cómo ambos regidores fueron a Carchenilla a tomar posesión de las casas que Pedro de Madrid había vendido a Francisco de Cienfuegos. Estando allí, amenazaron al dicho Fernando Sánchez, forzándole a que aceptase también vender su casa y propiedades al yerno de Ruy García ${ }^{50}$. En cualquier caso, debemos ser cautelosos a la hora de aceptar este testimonio, pues una denuncia como ésta bien podía construirse como elemento estratégico en su discurso jurídico, ajustándose poco o nada a la realidad.

48. Una de las medidas adoptadas por el regimiento talaverano para asegurar la producción vitivinícola de la villa fue la prohibición de plantar nuevos viñedos en la zona sur-sureste del alfoz, conocida como La Jara. Este territorio, que comprendía las poblaciones de Alía, Castilblanco, Valdecaba1leros, La Estrella, Garvín, Valdelacasa, La Peraleda y San Román, elevó numerosas quejas al concejo y al arzobispo. El primero de ellos, no dudó en utilizar todos los medios a su alcance para mantener dicha prohibición, enviando a jueces pesquisidores, regidores, alcaldes y alguaciles para que resolvieran las quejas, emitieran veredicto y ejecutasen las penas. En una de estas ocasiones, en 1463, Ruy García fue uno de los encargados de solventar las quejas de estos concejos (AMT, Jurisdicción, 1008, s/n). El enfrentamiento entre Talavera y La Jara llegó a la instancia arzobispal, en un pleito mantenido en 1472. Finalmente, la voluntad del concejo cabecera del alfoz prevaleció sobre el resto de poblaciones. A principios del siglo XVI, Talavera levantó la prohibición de plantar nuevos viñedos en dichos lugares a cambio del pago de ciertos cánones como compensación por las pérdidas sufridas por los viticultores talaveranos. Para más información sobre la comarca de La Jara a finales de la Edad Media, y el pleito por la plantación de vides, véase A. López Gómez y J. López Gómez. "Las comarcas toledanas según las "Relaciones Topográficas" de Felipe II", Boletín de la Real Academia de la Historia, 187/3 (1997), pp. 351-354; y M.J, Suárez Álvarez. La villa de Talavera y su tierra, pp. 361-364.

49. AGS, RGS, Legajo 148010,97.

50. AMT, Propios, 971, expedientes 3 y 4. 


\section{El patrimonio de Ruy García de la Rúa.}

A través de la información presentada por Juan García de la Rúa en 1451 y 1468 sobre sus fiadores, entre los que se encontraba su hermano Ruy, hemos podido conocer el grueso de las propiedades del regidor talaverano y la evolución del valor de éstas durante estas casi dos décadas.

Según Gonzalo Ruiz de Sevilla, Juan Gutiérrez Fernández y Fernando Franco, vecinos de Toledo, testigos presentados por Juan García para dar información sobre sus fiadores en el pedido y 4 monedas del arcedianazgo de Toledo de 1451, parece que en esta época, Ruy García, al que todos señalan al servicio de Pedro de Acuña en la corte, tendría entre 32 y 35 años. Gonzalo Ruiz, afirmaba que tenía unas casas en Toledo y que oyó decir que tenía otras casas muy buenas en Talavera. Según el testigo, parte de ellas fueron heredadas y algunas otras compradas con su propio capital. Tanto Juan Gutiérrez Fernández como Fernando Franco coinciden en señalar que Ruy García poseía ciertos inmuebles en Toledo, precisando el último que las casas que había recibido como herencia de sus suegros, los padres de su esposa, María Álvarez, estaban cerca de la iglesia de Santa María la Blanca. Según el primero, el valor total de sus propiedades ascendía a 120.000 maravedíes, cifra completamente dispar a la que dan los otros dos testigos, quiénes estiman que sus bienes podrían valer en torno a los 40.000 maravedíes $^{51}$.

En 1468, más de una década después de su nombramiento como regidor, vemos cómo su patrimonio se ha incrementado considerablemente. Según el testimonio de Lope Martínez Arroyo y Alfonso González de la Cámara, algo más escueto que el de 1451, Ruy García estaba afincado en Talavera, donde compaginaba su labor como regidor y la explotación de su hacienda. El primero de los testigos asegura que tenía unas casas, viñas y heredades en Talavera y su tierra, cuyo valor superaba los 300.000 maravedíes. Alfonso González únicamente se limita a indicar su condición de oficial del regimiento y a estimar también los 300.000 maravedíes como valor de los bienes de Ruy, precisando que éste los poseía desde hacía más de quince años ${ }^{52}$.

A través de otras fuentes documentales, hemos podido conocer con algo más de exactitud parte del patrimonio de Ruy García. Entre sus bienes rústicos contaba con la heredad de Valdefuentes, al norte del Tajo (no confundir con la dehesa homónima, propiedad de los señores de Oropesa), en la que debían pacer sus ganados, tal como indican los registros de los oficiales municipales ${ }^{53}$. En 1458, Ruy García pidió que se revisase la demarcación de esta heredad, puesto que se quejaba de ser pequeña. Comisionaron a Lope González, Álvaro de Loaísa, Fernando de

51. AGS, EMR, Legajo 4, ff. 27v-27bis r.

52. AGS, EMR, Legajo 15, f. 395r.

53. AMT, Jurisdicción, 1010, expediente 7, s/f. También se indica la propiedad de Ruy García sobre Valdefuentes en uno de los testimonios presentados en el pleito que Talavera mantuvo con Fernando de Tovar y su esposa, María de Torres, por la dehesa de Castillejo (ARCV, Pl. Civiles. Alonso Rodríguez (F). Caja 0757.001/0759.001). M.J. Suárez además le atribuye la posesión de Torrecilla, otra heredad cercana a Valdefuentes (M.J. Suárez Álvarez. La villa de Talavera y su tierra, p. 271). 
Talavera, regidores, y a Fernando García, procurador, para que comprobasen si efectivamente en realidad la heredad era mayor, y les dieron poder para que restablecieran los límites originales de la propiedad en caso de ser cierta la queja del regidor ${ }^{54}$.

En 1479, con motivo del casamiento de Rodrigo de la Rúa, hijo de su hermano, el bachiller Fernán García de la Rúa, Ruy le dona un censo de 450 maravedíes y tres pares de gallinas sobre tres casas que tenía repartidas por la villa. La primera de ellas era una casa y tierra, arrendada a Miguel Sánchez, en la calle que va de la Puerta de Mérida a San Antón, extramuros de la villa, que lindan con casas de su difunto hermano Fernán. Por ellas, recibía anualmente 150 maravedíes y un par de gallinas. Por otra tierra y casa que tenía Jerónimo, criado de Pedro Sánchez, clérigo, que linda con la huerta de Esteban Barbas, y con el cementerio de San Andrés, recibía 100 maravedíes y otro par de gallinas. Finalmente, la casa y tierra arrendada a Juan Sánchez de Nieva, lindera con el cementerio de San Cristóbal y con el camino que va al monasterio de San Francisco, percibía cada año 200 maravedíes y otro par de gallinas ${ }^{55}$.

\section{CONCLUSIONES}

El desarrollo de la carrera de Ruy García de la Rúa puede tomarse como un ejemplo de ascenso social a través del clientelismo político y económico. El posicionamiento de Ruy García como fiador de su hermano, Juan García, y el socio de éste, Ruy González de San Martín, le valió para mantenerse cerca de la gestión que ambos financieros realizaban de las rentas regias en los arcedianazgos de Talavera y Toledo, principalmente, aunque sin llegar a alcanzar su completo control, salvo en los casos en los que actuó como arrendador. Esta posición central en la red de relaciones de ambos recaudadores, especialmente en la de Juan, le valió para establecer contactos con otros hombres importantes en el ámbito físcal, como Rodrigo de la Fuente, con el que emprendió el arrendamiento de las monedas del arcedianazgo de Toledo a principios de la década de 1450. Si bien esta cooperación entre ambos pudo deberse a una estrategia seguida por sus respectivos grupos financieros, le sirvió de base y experiencia a Ruy, quien se encargó en solitario de parte de las albaquías del reino hasta 1452 .

A pesar de estas incursiones en el mundo financiero, sus intereses estaban en el ámbito político. El contacto que mantuvo la familia con los arzobispos de Toledo, a través de Fernán García en principio, pero, sobre todo, mediante el servicio prestado por Ruy García a Pedro de Acuña, hermano de Alonso Carrillo, les sirvió para mantenerse cerca del poder municipal y, paulatinamente, ascender en la escala social hasta alcanzar, ya en 1456, la regiduría por el nombramiento directo del arzobispo, hecho nada habitual en Talavera de la Reina, a diferencia de lo que

54. AMT, LLAA, 1450-1459, f. 234r.

55. ACT, 266, 20. 
sucedía en otros concejos castellanos. A pesar de la protesta del resto de oficiales municipales, que defendían los usos y costumbres de la villa, y sus propios intereses individuales y de grupo, el prelado se mantuvo firme en su decisión. Con anterioridad, Ruy García había recibido como merced de Juan II el cargo de juez de fieldad de Toledo, por renuncia de Rodrigo de Vera. Es muy posible que en este nombramiento también hubieran intercedido los Acuña en su nombre.

La merced que recibió en 1456 de manos del arzobispo Carrillo, le sirvió para incorporarse y asentarse en el regimiento talaverano, siendo comisionado para las más variadas actuaciones en nombre del concejo. Sin duda, su experiencia en la corte, al servicio del conde de Buendía, debió prevalecer para que en 1480 fuera ante los reyes para defender los intereses de Talavera frente a Fernando de Monroy.

Con el paso del tiempo, su poder e influencia fue aumentando, logrando incluso entablar relaciones familiares con otros miembros del regimiento, como Francisco de Cienfuegos, casado con Elvira de la Rúa; o Diego López de Ayala, señor de Cebolla, de quien fue criado Rodrigo de la Rúa, sobrino de Ruy. Aunque no lograron mantener ninguna de las regidurías que Ruy García y Francisco de Cienfuegos habían ostentado, en los primemos años del Quinientos todavía encontramos a miembros del linaje, como Francisco de la Rúa o Hernando de la Rúa, ocupando oficios que les permitieron continuar en el entorno del gobierno municipal. El primero de ellos, Francisco de la Rúa, fue mayordomo y procurador de Diego López de Ayala, y tras la muerte de éste, trabajó a las órdenes de su hijo y sucesor en el señorío de Cebolla, Juan de Ayala. Hernando de la Rúa tuvo una presencia más activa en la política talavera de comienzos de este siglo. En 1501, se presenta ante el concejo como procurador de la $\mathrm{Mesta}^{56}$, y siete años después, en 1508 , fue nombrado escribano del concejo ${ }^{57}$. Este cargo le proveyó de la confianza necesaria para que unos meses después, en mayo de 1509 , le dieran poder para acudir ante los contadores mayores a renovar el encabezamiento de las alcabalas de Talavera ${ }^{58}$.

Como hemos visto, la familia García de la Rúa logró posicionarse como uno de los linajes que integraban la élite de poder en el marco urbano de Talavera de la Reina durante la segunda mitad del siglo XV, y lograron mantenerse, ya en el siglo XVI, como parte de la élite de participación, con acceso a determinados recursos gracias a los vínculos que habían establecido con los principales personajes que rigieron la villa durante estos años. 


\section{Bibliografía CITADA.}

Alonso García, David. "Entre Granada y Castilla. La familia Fuente y la hacienda real a comienzos de la Edad Moderna", Investigaciones históricas: época moderna y contemporánea, 25 (2005), pp. 11-30.

- " "Poder financiero y arrendadores de rentas reales en Castilla a principios de la Edad Moderna”, Cuadernos de Historia Moderna, 31 (2006), pp. 117-138.

—. "Capital privado y fiscalidad regia en Castilla a comienzos de la Edad Moderna", en La fiscalità nell'economia europea secc. XIII-XVIII. Florencia, 2008, vol. II, pp. 793-800.

—. "Notas sobre la cooperación en el arrendamiento de rentas reales (15001525)", en IX Congreso Internacional de la Asociación Española de Historia Económica. Murcia, 2008, pp. 1-26.

Álvarez García, Carlos. "Los judíos y la hacienda real bajo el reinado de los Reyes Católicos. Una compañía de arrendadores de rentas reales”, en Las Tres Culturas en la Corona de Castilla y los sefardies. Salamanca, 1990, pp. 87-125.

Fornell Fernández, Francisco Javier. Linajes gaditanos en la Baja Edad Media. Breve estudio de la oligarquía local (siglos XIII-XV). Cádiz, 2010.

Gómez-Menor, José Antonio. La antigua tierra de Talavera. Bosquejo histórico y aportación documental. Toledo, 1965.

Jara Fuente, José Antonio. Concejo, poder y élites: la clase dominante de Cuenca en el siglo XV. Madrid, 2000.

—. "Elites urbanas y sistemas concejiles: una propuesta teórico-metodológica para el análisis de los subsistemas de poder en los concejos castellanos de la Baja Edad Media”, Hispania, Revista Española de Historia, LXI/1, núm. 207 (2001), pp. 221-266.

-. "Estructuras formales de poder y de organización de las clases dominantes urbanas en Castilla: el regimiento: una crisis del siglo XIV en el siglo XV", Edad Media: revista de historia, 8 (2007), pp. 225-241.

-. "Attributing social fields and satisfying social expectations: the urban system as a circuit of power-structuring relations (Castile in the fifteenth century" en Oligarchy and patronage in late medieval Spanish urban society. Turnhout, 2009.

—. "Percepción de «sí»», percepción del «otro»: la construcción de identidades políticas urbanas en Castilla (el concejo de Cuenca en el siglo XV)", Anuario de Estudios Medievales, 40/1 (2010), pp. 75-92.

- . "Por el conosçimiento que de él se ha". Identificar, designar, atribuir: la construcción de identidades (políticas) en Cuenca en el siglo XV", Hispania: revista española de historia, vol. LXXI, núm. 238 (2011), pp. 389-408.

Ladero Quesada, Miguel Ángel. “La receptoría y pagaduría general de la Hacienda regia castellana entre 1491 y 1494: de Rabí Meír Melamed a Fernán Núñez Coronel”, En la España Medieval, 25 (2002), pp. 425-506.

Layna Serrano, Francisco. Historia de la villa de Cifuentes. Guadalajara, 1979. 
López Gómez, Antonio y López Gómez, Julia. “Las comarcas toledanas según las "Relaciones Topográficas" de Felipe II", Boletín de la Real Academia de la Historia, 187/3 (1997), pp. 337-362.

López Gómez, Óscar. Violencia urbana y paz regia: el fin de la época medieval en Toledo (1465-1522), Tesis doctoral inédita, 2006.

Mackay, Angus. "Documentos para la historia de los financieros castellanos de la Baja Edad Media. I: una “información” del 23 de septiembre de 1466”, Historia, Instituciones, Documentos, 5 (1978), pp. 321-328.

Molina González, José Luis. "El estudio de las redes personales: contribuciones, métodos y perspectivas", Empiria. Revista de metodología de Ciencias sociales, 10 (2005), pp. 71-105.

Monsalvo Antón, José María. El sistema político concejil: el ejemplo del señorío medieval de Alba de Tormes y su concejo de villa y tierra. Salamanca, 1988.

—. "Poder político y aparatos de estado en la Castilla bajomedieval: consideraciones sobre su problemática", Studia histórica. Historia medieval, 4 (1986), pp. 101-169.

—. "El reclutamiento del personal político concejil: la designación de corregidores, alcaldes y alguaciles en un concejo del siglo XV", Studia histórica. Historia medieval, 5 (1987), pp. 173-196.

—. "Parentesco y sistema concejil: observaciones sobre la funcionalidad política de los linajes urbanos en Castilla y León (siglos XIII-XV)", Hispania: Revista española de Historia, vol. LIII, 185 (1993), pp. 937-969.

—. "Los espacios de poder en la ciudad medieval: impresiones a partir de cuatro casos: León, Burgos, Ávila y Salamanca”, en J.I. de la Iglesia Duarte y J.L. Martín Rodríguez (coords.), Los espacios de poder en la España medieval: XII Semana de estudios medievales, Nájera, del 30 de julio al 3 de agosto de 2001. Logroño, 2002, pp. 97-147.

- " "Gobierno municipal, poderes urbanos y toma de decisiones en los concejos castellanos bajomedievales (consideraciones a partir de concejo salmantinos y abulenses)", en Las sociedades urbanas en la España medieval. XXIX Semana de Estudios Medievales, Estella, 15 a 19 de julio de 2002. Pamplona, 2003, pp. 409-488.

- (coord.). Sociedades urbanas y culturas políticas en la Baja Edad Media castellana. Salamanca, 2013.

Morales Muñiz, Dolores Carmen. "La concesión del título de (I) conde de Buendía por el rey Alfonso XII de Castilla (1465) como expresión del poder del linaje Acuña", Espacio, Tiempo y Forma. Serie III. Historia Medieval, 19 (2007), pp. 197-210.

Moreno Koch, Yolanda. "Diez años de actividad económica en el reinado de los Reyes Católicos: Rabí Meir Melamed (Fernán Núñez Coronel)”, en A. Meyuhas Ginio y C. Carrete Parrondo (coords.), Creencias y Culturas. Salamanca, 1998, pp. 159-168. 
Ortega Cervigón, José Ignacio. "El arraigo de los linajes portugueses en la Castilla bajomedieval: el caso de los Acuña en el obispado de Cuenca", Medievalismo: Boletín de la Sociedad Española de Estudios Medievales, 16 (2006), pp. 73-92.

Ortego Rico, Pablo. "Auge y caída de una gran compañía financiera en Castilla: Luis de Alcalá, Rabí Mayr y la quiebra de la receptoría y pagaduría general de rentas (1477-1495)", en E. García Fernández e I. Vitores Casado, Tesoreros, “arrendadores" y financieros en los reinos hispánicos: la Corona de Castilla y el reino de Navarra (siglos XIV-XVII), Madrid, Instituto de Estudios Fiscales, 2012, pp. 101-122.

Peña Barroso, Efrén. "Firmas y rúbricas de judeoconversos de la compañía de arrendadores Coronel-Alcalá", Seferad, 71/1 (2011), pp. 201-208. http:// dx.doi.org/10.3989/sefarad.011.006

- " "Las propiedades rústicas de una familia de conversos segovianos: los Seneor/ Coronel”, Espacio, Tiempo y Forma, Serie III, Historia Medieval, 24 (2011), pp. 319-352.

Rabadé Obradó, María Pilar. "El proceso inquisitorial contra Fernando de la Fuente, veterano de la guerra de Granada (1505-1506)", en M.I. del Val Valdivieso y P. Martínez Sopena (coords.), Castilla y el mundo feudal. Homenaje al profesor Julio Valdeón, Valladolid, 2009, vol. II, pp. 319-332.

Rodríguez-Picavea Mantilla, Enrique. Orígenes y desarrollo de la señorialización en la villa de Talavera y su tierra (siglos XIII-XV). Talavera de la Reina, 2007.

Suárez Álvarez, María Jesús. La villa de Talavera y su tierra en la Edad Media (1369-1504). Oviedo, 1982.

—. "La expansión del régimen señorial con Enrique de Trastámara: el ejemplo de Talavera de la Reina", En la España Medieval, 7 (1985), pp. 1133-1158.

Val Valdivieso, María Isabel del. "La sociedad urbana del señorío de Vizcaya en la baja Edad Media”, En la España Medieval, 7 (1985), pp. 317-335.

—. "Dinámica social en las ciudades castellanas en torno a 1494", en L.A. Ribot García, A. Carrasco Martínez y L.A. da Fonseca (coords.), El tratado de Tordesillas y su época. Congreso Internacional de Historia, Madrid, 1995, pp. 113-135.

-. "The urban oligarchy's affairs in the Government of Castilian Towns in the Late Middle Ages", en M. Boone y P. Stabel (eds.): Shaping urban identity in Late Medieval Europe, 2000, pp. 255-267.

—. "La identidad urbana a finales de la Edad Media", Anales de Historia Medieval de la Europa atlántica, 1 (2006), pp. 5-28.

Fecha de recepción del artículo: febrero de 2014

Fecha de aceptación y versión final: abril de 2014 